
Pojazdy elektryczne nie emitują zanieczyszczeń ani hałasu i z tego względu nadają się szczególnie do stosowania w obszarach miejskich. Konfiguracje hybrydowe, łączące silniki spalinowe wewnętrznego spalania z silnikami elektrycznymi, umożliwiają zmniejszenie zużycia ropy naftowej i emisji $\mathrm{CO}_{2}$ dzięki poprawie ogólnej efektywności energetycznej napędu. Technologia pojazdów elektrycznych staje się coraz dojrzalsza, a ich rozpowszechnienie przyspiesza. Państwa członkowskie zabiegają o to, aby w 2020 r. jeździło po drogach 8-9 mln pojazdów elektrycznych [8].

\section{Autobusy hybrydowe Volvo}

Szlaki elektrobusom przecierają pojazdy o napędzie hybrydowym. Autobusy tego typu zużywają 30-40\% mniej paliwa i emitują 40$50 \%$ mniej spalin w porównaniu z analogicznymi autobusami z napędem diesla. Są też bardzo ciche. Wszystko to sprawia, że są dużo przyjaźniejsze dla środowiska niż tradycyjne autobusy napędzane silnikami diesla [7].

Dotychczas największą flotą hybryd w Polsce dysponował Inowrocław - jeździ tam m.in. 10 tego typu autobusów dostarczonych przez Volvo w 2016 r. Kolejnym miastem stawiającym na hybrydy jest Sosnowiec - w ramach kontraktu zawartego z sosnowieckim przedsiębiorstwem komunikacji miejskiej Volvo dostarczyło 35 hybrydowych autobusów miejskich Volvo 7900 Hybrid - 25 krótkich i 10 przegubowych. To jak do tej pory największa jednorazowa dostawa pojazdów z napędem hybrydowym w Polsce i jednocześnie pierwsze przegubowe hybrydy odebrane przez polskiego przewoźnika. Hybrydy Volvo spotkać też można w Warszawie i we Wrocławiu.

\section{Elektryczne hybrydy Volvo}

Elektryczne hybrydy tym różnią się od „tradycyjnych”, że na większości trasy wykorzystują energię elektryczną. W swojej wrocławskiej fabryce Volvo produkuje autobus Volvo 7900 Electric Hybrid, który porusza się cicho i nie wytwarza spalin na 70\% trasy. Ładowanie baterii trwa tylko 3-6 min i odbywa się na przystanku końcowym. Jest to możliwe dzięki wykorzystaniu systemu ładowania opportunity charging - autobus po prostu podjeżdża pod stację ładowania i pobiera prąd przez pantograf wysuwany ze stacji. Akumulatory są też ładowane podczas jazdy - przy hamowaniu i z nadwyżki mocy. Dzięki takiemu rozwiązaniu zużycie energii jest o 60\% niższe niż w przypadku porównywalnego autobusu z silnikiem diesla, a emisja dwutlenku węgla zostaje zredukowana aż o 75\%.

Elektryczna hybryda to jednak nie tylko mniejsze zanieczyszczenie i oszczędność energii. To także możliwość aktywnego zarządzania napędem w strefach, w których porusza się autobus. Podczas gdy klasyczne hybrydy automatycznie przełączają się pomiędzy napędem spalinowym i elektrycznym (elektryczny wykorzystywany jest przy ruszaniu i przy małych prędkościach), to w przypadku elektrycznych hybryd istnieje możliwość zaprogramowania, w którym momencie autobus będzie wykorzystywał napęd elektryczny, a w którym spalinowy. System umożliwia dokładne skalkulowanie zapotrzebowania na energię na danej trasie i wgranie do komputera sterującego praca jednostki napędowej algorytmu, który automatycznie, po odczytaniu danych z GPS, przełączy napęd ze spalinowego na elektryczny w strefach nisko- bądź zeroemisyjnych, np. w okolicach szkół, szpitali, osiedli mieszkaniowych czy centrów miast.

$Z$ perspektywy miast to rozwiązanie wydaje się bardzo interesujące, pozwala na zupełnie inne spojrzenie na kwestie projektowania. Możliwe jest tworzenie stref zeroemisyjnych, wolnych od spalin - elektryczna hybryda ma możliwość przejazdu w pełni elektrycznego w takich strefach. Co więcej, autobus taki może mieć np. przystanek wewnątrz galerii handlowej, gdzie będzie się poru- szał wyłącznie przy wykorzystaniu energii elektrycznej, a więc cicho i bezemisyjnie.

Elektryczne hybrydy Volvo kursują już w takich miastach jak Göteborg, Sztokholm, Hamburg, Luksemburg, Namur czy Kurytyba. W samym tylko Luksemburgu istnieją 4 linie autobusowe o łącznej długości 86 km, złożone wyłącznie z elektrycznych hybryd - w sumie jest to flota 17 pojazdów.

\section{Kierunki rozwoju elektromobilności Volvo}

Wrażliwe obszary, takie jak zatłoczone centra miast i dzielnice mieszkaniowe, wymagają utrzymania poziomu spalin i hałasu na minimalnym poziomie. W takim przypadku najlepszym rozwiązaniem jest napęd elektryczny. Volvo 7900 Electric, dzięki możliwości szybkiego ładowania (6 min) na przystankach końcowych i dużej pojemności akumulatora, ma możliwości przewozowe nie różniące się od oferowanych przez konwencjonalne autobusy. Autobus zużywa o 80\% mniej energii w porównaniu z napędem konwencjonalnym, porusza się cicho, na całej trasie napędzany jest wyłącznie energią elektryczną, nie emituje więc spalin, emisja dwutlenku węgla zredukowana zostaje o 99\%.

W pełni elektryczne autobusy Volvo obsługują już linie miejskie w Göteborgu czy Luksemburgu, a ostatnio przewoźnik Nobina z Malmö zamówił we wrocławskiej fabryce Volvo 13 elektrycznych pojazdów, które zaczną kursować na terenie Malmö pod koniec przyszłego roku. Jest to jak dotąd największe pojedyncze zamówienie na Volvo 7900 Electric.

Doświadczenia w zakresie rozwoju elektromobilności zdobywa Volvo w ramach projektu ElectriCity. Miejscem narodzin ElectriCity - wspólnego, a przy tym niezwykle ekscytującego przedsięwzięcia łączącego w sobie dokonania przemysłu, wyniki najnowszych badań oraz zaangażowanie samych mieszkańców - jest Göteborg. Nadrzędnym celem projektu jest rozwój oraz testowanie rozwiązań przeznaczonych dla nowej generacji zrównoważonego transportu publicznego. Projekt ElectriCity tworzy również taką platformę dla rozwoju i testowania produktów i usług, która może znacząco przyczynić się do uatrakcyjnienia transportu publicznego. Nowe rozwiązania skierowane są w stronę systemów zarządzania ruchem i koncepcji bezpieczeństwa, ulepszania przystanków oraz systemów zaopatrzenia w energię i jej magazynowania.

Najbardziej zauważalnym wynikiem współpracy opisanej powyżej jest linia autobusowa 55, na której od czerwca 2015 r. kursuje 10 całkowicie i częściowo elektrycznych autobusów zasilanych energią elektryczną pochodzącą ze źródeł odnawialnych. Autobusy linii 55 rozpoczęły kursy pomiędzy kampusami Uniwersytetu Technologicznego Chalmers w Johanneberg i Lindholmen. 3 pokazowe autobusy, poruszające się dzięki odnawialnej energii elektrycznej uzyskanej z wiatru i energii wodnej, są wyjątkowo energooszczędne, ciche i całkowicie bezemisyjne. Autobus elektryczny wyposażony jest w silnik elektryczny zasilany z akumulatorów litowo-jonowych. Ilekroć pojazd zwalnia, powstający wówczas „efekt hamowania” generuje elektryczność, która wykorzystywana jest do ładowania akumulatorów. Ładowanie odbywa się również za pośrednictwem sieci elektrycznej na 2 przystankach końcowych.

Istotny wpływ na projekt elektrycznych autobusów miały oczekiwania pasażerów spodziewających się przyjemnej atmosfery oraz praktycznych funkcji wewnątrz pojazdów. Nowoczesny design i zastosowane materiały zachęcają mieszkańców miasta do korzystania z transportu publicznego. Wchodzenie i wychodzenie pasażerów z pojazdów odbywa się szybko i wygodnie dzięki szerokim drzwiom usytuowanym w środkowej części autobusu. Znajduje się tam również duża, otwarta przestrzeń z niską i płaską podło- 
gą, co stanowi bardzo duże ułatwienie dla pasażerów z wózkami dziecięcymi oraz osób niepełnosprawnych poruszających się na wózkach inwalidzkich. W autobusach pasażerowie mają swobodny dostęp do najnowszych technologii. Pojazdy wyposażone są w Wi-Fi oraz gniazdka zasilające, jak również w elektroniczne tablice wyświetlające informacje i wiadomości. Przystanek autobusowy przy Teknikgatan w Lindholmen znajduje się w całkowicie zadaszonym pomieszczeniu. Jest to pierwsze takie rozwiązanie, dzięki któremu pasażerowie mogą wsiąść lub wysiąść z autobusu w zamkniętym budynku. W praktyce oznacza to, że zamiast czekać na autobus pod gołym niebem, mogą spędzić ten czas w pomieszczeniu doskonale zabezpieczonym przed wiatrem i deszczem. Mogą również odwiedzić kawiarnię i naładować telefony dzięki portom USB [9, 10].

Po 2 udanych latach kursowania elektrycznych autobusów na trasie 55 partnerzy przedsięwzięcia ElectriCity zdecydowali o zwiększeniu ruchu autobusów elektrycznych w mieście. W czerwcu przyszłego roku, kiedy w Göteborgu będzie odbywać się Volvo Ocean Race, 2 elektryczne autobusy przegubowe kursujące pomiędzy centrami handlowymi Nordstan i Frihamnen bedą reprezentować najnowsze osiągnięcia techniczne. Te 2 prototypowe autobusy będą później kursować na trasie 16, która zostanie wyposażona w infrastrukturę do ładowania i przystanki autobusowe przystosowane do ruchu pojazdów elektrycznych o wysokiej przewoźności. Powstaną między innymi nowe stacje ładowania w Eriksbergstorget i Sahlgrenska Hospital [9].

\section{Podsumowanie}

Zmiany w sektorze transportu są niezbędne, jeśli zamierza się stworzyć zrównoważone społeczeństwo i miasta nowej generacji. Należy więc wprowadzić w miastach zrównoważony transport, który oznacza konieczność modernizacji istniejących rozwiązań i potrzebę dokonywania nowych inwestycji, który jednocześnie kreuje nowe narzędzia dla dalszego wzrostu gospodarczego, zdrowszego społeczeństwa, a także pozwala przyjąć na siebie część wspólnej odpowiedzialności za przyszłość klimatu i środowiska. Projekt ElectriCity jest znakomitym przykładem owocnej współpracy miasta, firm i instytucji akademickich. Po 2 latach od uruchomienia pilotażowego programu transportu publicznego, w którym 100 tys. podróżnych miało okazję przetestować nowe produkty i usługi wzdłuż $8 \mathrm{~km}$ trasy, można wskazać konkretne korzyści środowiskowe, gospodarcze,

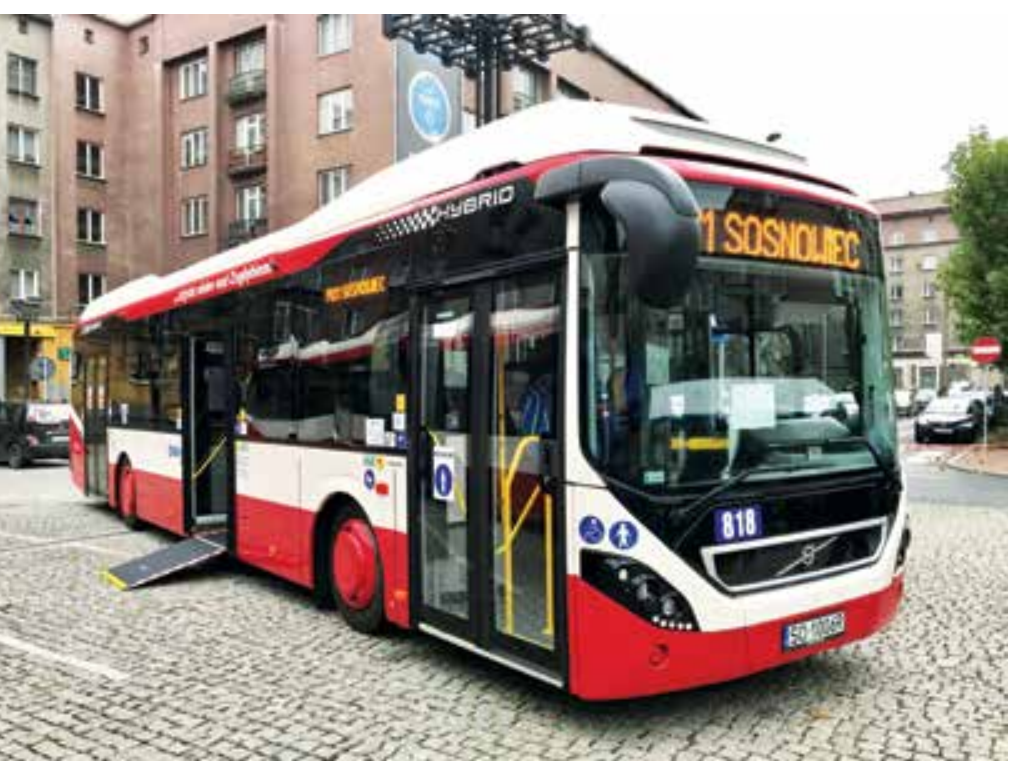

Volvo 7900 Hybrid dostarczony w 2017 r. do Sosnowca. Fot. Volvo

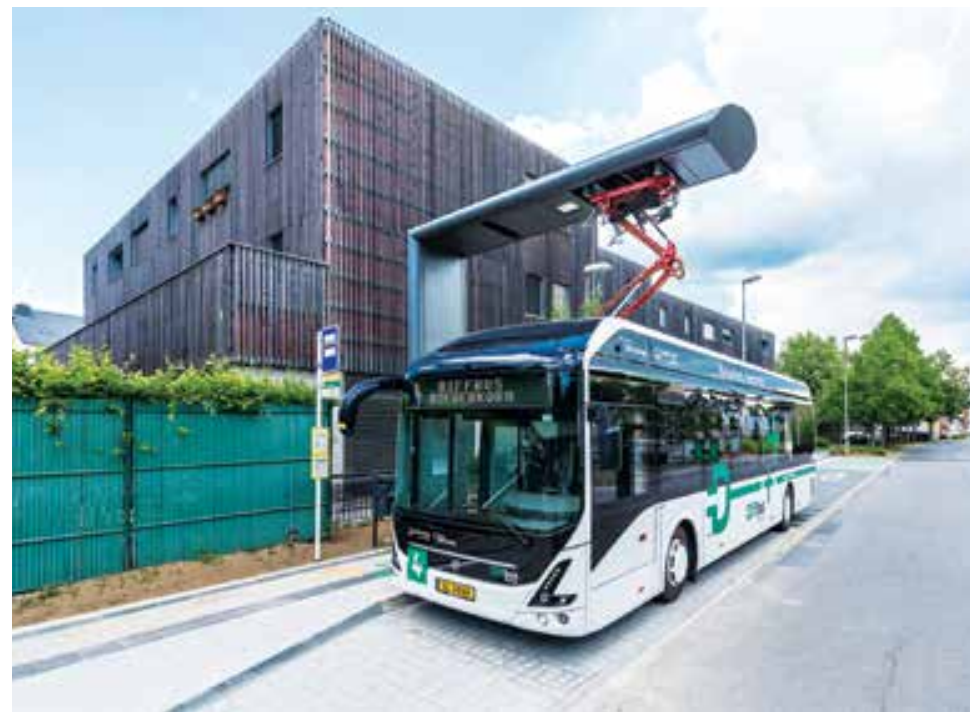

Volvo 7900 Electric w Differdange (Luksemburg) na stacji ładowania energii. Fot. Volvo

zdrowotne i społeczne. Zelektryfikowane autobusy redukują emisję szkodliwych substancji. Mniejszy hałas i zredukowana emisja $\mathrm{CO}_{2}$ przekładają się na lepsze wyniki zdrowia społeczności, a także nie wpływają negatywnie na miejską zabudowę. Także satysfakcja użytkowników na trasie jest bardzo wysoka, udało się bowiem stworzyć warunki do wygodnego i bezproblemowego transportu, w ramach którego pasażer, dzięki najnowszej technologii, może podczas jazdy zająć się swoimi potrzebami i zainteresowaniami.

\section{Bibliografia:}

1. BIAŁA KSIEGA Plan utworzenia jednolitego europejskiego obszaru transportu - dążenie do osiągnięcia konkurencyjnego i zasobooszczędnego systemu transportu, COM(2011) 144.

2. Brożek K., Kogut J., Projekt ElectriCity jako instrument zrównoważonego rozwoju transportu publicznego, „Autobusy - Technika, Eksploatacja, Systemy Transportowe" 2016, nr 12.

3. Dyr T., Europejska polityka transportowa na pierwszą połowę XXI wieku, „Autobusy - Technika, Eksploatacja, Systemy Transportowe" 2011, nr 10.

4. Dyr T., Europejska strategia w zakresie paliw alternatywnych, „Autobusy - Technika, Eksploatacja, Systemy Transportowe” 2013, nr 11.

5. ElectriCity. Exciting cooperation for sustainable public transport: https://www.goteborgelectricity.se/en (dostęp: 09.08.2017 r.).

6. EUROPA 2020 Strategia na rzecz inteligentnego i zrównoważonego rozwoju sprzyjającego włączeniu społecznemu, $\operatorname{COM}(2010) 2020$.

7. Komunikat Komisji do Parlamentu Europejskiego, Rady, Europejskiego Komitetu Ekonomiczno-Społecznego i Komitetu Regionów Czysta energia dla transportu: europejska strategia w zakresie paliw alternatywnych, $\operatorname{COM}(2013) 17$.

8. Pawlak G., Miejskie autobusy hybrydowe Volvo, „Autobusy Technika, Eksploatacja, Systemy Transportowe” 2012, nr 1-2.

9. Tyl M., Elektromobilność w strategii Volvo, „Autobusy - Technika, Eksploatacja, Systemy Transportowe” 2015, nr 6.

\section{Autorka:}

mgr Małgorzata Kozłowska - doktorantka na Wydziale Nauk Ekonomicznych i Prawnych Uniwersytetu Technologiczno-Humanistycznego w Radomiu 